\title{
Assessing the Effectiveness of Monitoring Control and Surveillance of Illegal Fishing: The Case of West Africa
}

\begin{abstract}
Alkaly Doumbouya ${ }^{1}$, Ousmane T. Camara ${ }^{1}$, Josephus Mamie ${ }^{2}$, Jeremias F. Intchama ${ }^{3}$, Abdoulie Jarra ${ }^{4}$, Salifu Ceesay ${ }^{5}$, Assane Guèye ${ }^{6}$, Diène Ndiaye ${ }^{7}$, Ely Beibou ${ }^{8}$, Allan Padilla ${ }^{9}$ and Dyhia Belhabib ${ }^{9 *}$

${ }^{1}$ Centre National des Sciences Halieutiques de Boussoura, Conakry, Guinea, ${ }^{2}$ Ministry of Fisheries and Marine Resources, Freetown, Sierra Leone, ${ }^{3}$ Centro de Investigaçao Pesqueira Aplicada, Bissau, Guinea Bissau, ${ }^{4}$ Ministry of Fisheries, Independant Consultant, Banjul, Gambia, ${ }^{5}$ Department of Fisheries, Ministry of Fisheries, Banjul, Gambia, ${ }^{6}$ Direction de la Protection et de la Surveillance des Pêches, Dakar, Senegal, ${ }^{7}$ Direction des Industries de Transformation de la Pêche, Dakar, Senegal, ${ }^{8}$ Institut Mauritanien de Recherches Océanographiques et des Pêches, Nouadhibou, Mauritania, ${ }^{9}$ Sea Around Us, University of British Columbia, Vancouver, BC, Canada
\end{abstract}

\section{OPEN ACCESS}

Edited by:

Maria Lourdes D. Palomares, FishBase Information and Research Group, Philippines

Reviewed by:

Dimitrios K. Moutopoulos, Technological Educational Institute of Messolonghi, Greece Cornelia E. Nauen, Mundus Maris-Sciences and Arts for Sustainability, Belgium

*Correspondence: Dyhia Belhabib dyhia.belhabib@gmail.com

Specialty section: This article was submitted to Marine Fisheries, Aquaculture and Living Resources, a section of the journa Frontiers in Marine Science

Received: 12 November 2016 Accepted: 13 February 2017 Published: 07 March 2017

Citation:

Doumbouya A, Camara OT, Mamie J, Intchama JF, Jarra A, Ceesay $S$,

Guèye A, Ndiaye D, Beibou $E$ Padilla A and Belhabib D (2017) Assessing the Effectiveness of Monitoring Control and Surveillance of Illegal Fishing: The Case of West

Africa. Front. Mar. Sci. 4:50. doi: 10.3389/fmars.2017.00050
This paper assesses illegal fishing in West Africa, one of the regions most affected by Illegal, Unreported, and Unregulated fishing (IUU) in the world. The catch, the economic loss and the amount recovered through Monitoring, Control, and Surveillance (MCS) are calculated based on a reconstruction method, and the information made available through national MCS units, between 2010 and 2016 in an effort to assess the effectiveness of surveillance efforts in the region. Results show considerable loss of revenues for Mauritania, Senegal, The Gambia, Guinea Bissau, Guinea, and Sierra Leone, estimated at 2.3 billion USD annually, while a minimal amount of 13 million USD is recovered through MCS. In addition, this paper finds that countries touched by the Ebola crisis (Guinea and Sierra Leone) drive a tremendous increase in the loss generated by illegal fishing. However, further analysis shows that the overall severity of illegal fishing, as defined by a range of types investigated here, declines as the fines against the most severe forms of IUU fishing increase. Finally this study finds that Sierra Leone and The Gambia have the highest scoring MCS systems, and were the countries where the most offenders are caught and charged with the highest fines, while Senegal's new legislations which improved MCS during 2015 does not appear to show on the scoring results. This study finds that illegal fishing amounts the equivalent of $65 \%$ of the legal reported catch from West Africa and poses serious concern for food security, and the economy in the region.

Keywords: illegal fishing, IUU, catches, West Africa, economic values, sanctions, offenses, Monitoring Control and Surveillance

\section{INTRODUCTION}

There is growing concern with regards to the health of global fish stocks and the repercussions of their depletion on food security and the economy of most vulnerable countries (FAO, 2016). West African countries rely heavily on fish as a one of the principal sources of protein, but also as a source of income and employment for nearly 7 million people (Belhabib et al., 2015c). This 
region has seen its fish stocks decline, driven by over-exploitation, overcapacity, and illegal fishing (Daniels et al., 2016). Previous work assessed illegal fishing in the region (Belhabib et al., 2012c, 2016; Belhabib and Pauly, 2015) to nearly 40 per cent of all the fish caught-the highest level worldwide (Agnew et al., 2009). Not only the economy of vulnerable countries is threatened, illegal fishing is estimated to reduce the number of jobs in artisanal sectors by 300,000 (Daniels et al., 2016). Illegal fishing conducted by industrial vessels is very difficult to assess and existing estimates are bound with a high degree of uncertainty, as illegal fishing vessels are highly mobile and develop tedious techniques to escape surveillance, particularly that monitoring is limited in the region.

There are different drivers of illegal fishing, as we look at industrial fishing, we argue that economic gain is the most significant incentive (Le Gallic and Cox, 2006; Sumaila et al., 2006), alongside with the ability of simply doing so (AndrewsChouicha and Gray, 2005). This is mainly the case in the national waters or exclusive economic zones (EEZs) of the 6 West African countries (The Gambia, Guinea, Guinea-Bissau, Mauritania, Senegal, and Sierra Leone), whose Monitoring Control and Surveillance (MCS) systems are relatively weak.

MCS is often bound with country's indicators such as governance and corruption (Standing, 2006), which are very weak in the region. Poor governance and high corruption combined with high monitoring costs pose a serious concern on the sustainability of West African countries' efforts to combat illegal fishing. Examples in the region show that the presence of international funders helps combatting illegal fishing by adding transparency and increasing surveillance activities. This raises the question of the effectiveness of these systems, and how much of the loss to illegal, unreported, and unregulated fishing is recovered through MCS (fines and sanctions).

MCS efforts are further jeopardized by the use of "detection escape" techniques such as interfering with electronic monitoring systems, the use of different flags to hide vessel identity and escape prosecution, use of multiple boat names, and forgery of registration certificates in the region (J.M. pers. obs.). Several cases illustrate multiple violations of fishery laws within West Africa, and raised important attention on the issue of cost recovery, to allow MCS efforts to become sustainable and independent from foreign "funding" (MRAG, 2005; Greenpeace, 2006). Multiple infractions and low capability of prosecution given high rates of detection escape render MCS particularly vulnerable to lower budgets. This vulnerability limits the ability of West African countries to deter IUU fishing. In addition, losses generated by illegal fishing in the region are barely known which limits knowledge on real economic losses generated by such activity.

This paper seeks to assess economic loss caused by illegal fishing in West Africa and the effectiveness of enforcement in the period between 2010 and 2016. It builds, for the first time, a sanctions and illegal fishing database, and analyses the relationship between sanctions and severity of IUU and draws conclusions on the efforts to make to reduce illegal fishing in the region. It also discusses the implication of illegal fishing on the artisanal fisheries sector, food security, and the economy.

\section{METHODS}

\section{Study Area}

The study area covers six countries (Mauritania, Senegal, The Gambia, Guinea-Bissau, Guinea, and Sierra Leone). These countries are members of the West African Sub Regional Fisheries Commission (SRFC) ${ }^{1}$ and lay within the Canary Current Large Marine Ecosystem (CCLME) in the North and the Guinean Current Large Marine Ecosystem (GCLME) in the South. This makes West African waters particularly productive. The coastal zone of West Africa is an area of strategic interest for the socio-economic development and livelihood of 1.4 million people living along the coast, and fisheries therein can contribute up to $38 \%$ of the GDP (Belhabib et al., 2015c).

\section{Building a Comprehensive Database of Illegal Fishing Vessels, Offenses, and Sanctions}

We investigate illegal fishing occurrences in West Africa and cover multiple indicators between 2010 and 2016. These are: Vessel name, gear type, country where illegal fishing occurred (or country where a fine was issued), origin of the vessel (flag), amount of the fine paid (or otherwise issued, if not yet paid) converted into USD 2015 , year of illegal activity, offenses committed per vessel, other sanctions in addition to the fine (such as confiscation of vessel, catch, gear, etc.), and whether a sanction was issued at all. The main data were gathered from various media sources, and observations from various organizations (Environmental Justice Foundation, 2012; INTERPOL, 2014; Greenpeace, 2016a,b), complemented by information from the Department of Surveillance and Protection of Fisheries for Senegal, The MCS units of The Gambia, Sierra Leone and Guinea, and the Ministry of Fisheries of Guinea Bissau, while information for Mauritania were not available. In cases where sanctions were not reported (notably the case of Guinea and Guinea Bissau), the amount of the sanction was assumed to equate the minimum amount that is given under the Fisheries Act of the country for that offense, or the average based on the most recent historical fine amounts available for similar cases.

\section{Estimation of Illegal Catches}

We estimated illegal catches, i.e., catches by foreign fleets as per the definition of illegal fishing (Belhabib et al., 2014a) for each country following different approaches depending on data availability.

\section{Senegal}

Illegal catches for Senegal for the years 2010 and 2011 were extracted from Belhabib et al. (2014a) and were estimated based on the number of observed illegal fishing boats, their size and a modeled catch per unit of effort (Belhabib et al., 2014b). Given similar MCS efforts between 2011 and 2012, we assumed illegal catches were constant then, and they increased by $20 \%$ between 2012 and 2013 after the dismissal of the Russian vessels from Senegalese waters (Belhabib et al., 2014a, 2015a). This particularly applied after Russian vessels obtained licenses in other countries

\footnotetext{
${ }^{1}$ Cape Verde, also a member, is not included in this analysis.
} 
in the sub-region (notably, Guinea Bissau and Mauritania), as incursions to Senegalese waters at night were common (A.G. pers. observation). We then multiplied the illegal catch of 2013 by the variation between 2013 and 2014, and between 2014 and 2015 to estimate the illegal catch for 2014 and 2015. Variation rates were derived from the percentage of infractions (compared to the total observed vessels) found in the World Bank monitoring report (The World Bank, 2016). Fishing vessels observed by aerial/surface patrol or by radar and satellite monitoring that are committing a serious infraction in targeted fisheries represented $86 \%$ of the total in $2013,60 \%$ in 2014 , and $60 \%$ in 2015 (The World Bank, 2016).

\section{Guinea Bissau}

Two data points were available for Guinea Bissau. Surveillance activities found eight vessels fishing illegally during 1 week in 2014 (Caopa and Rejprao, 2016). Given the conservative nature of this estimate, we extrapolated year long and estimated a number of 52 vessels in 2014. This number was multiplied by a CPUE of 1,200 tøboat $^{-1} \bullet$ year $^{-1}$, which is the minimum an illegal trawler catches to cover its operation costs (Pauly et al., 2014; Belhabib et al., 2015b). We assumed the illegal catch was constant between 2014 and 2015 and interpolated linearly between the estimate in 2010 (18,000 t), provided by Belhabib and Pauly (2015) for Guinea Bissau.

\section{Guinea}

Illegal fishing in Guinea represents the equivalent of $64 \%$ of legal reported catches (Belhabib et al., 2012a). We first extracted the estimated illegal catch for Guinea from Belhabib et al. (2012a), and then multiplied the reported catch extracted from the Food and Agriculture Organization (FAO) FishStat database, by $64 \%$. Then we extrapolated the trend forwards to 2015 .

\section{Sierra Leone}

The number of vessels spotted fishing illegally, or estimated, was reported at 30 for $2011^{2}, 10$ in $2012^{3}$ (Finch, 2016), 7 in 2014 (NOAA, 2015), and 80 in $2015^{4}$ associated with the Ebola crisis. The Ebola crisis along with governance issues related to the cancelation of the World Bank project, a major contributor to the increase in MCS in 2012 and 2013, prompted low to virtually no monitoring after 2014. We interpolated the number of boats between 2012 and 2014 and then multiplied by a minimum CPUE of 446 t•boat $^{-1} \bullet$ year $^{-1}$ for the industrial fleet operating in Sierra Leone (Seto et al., 2015).

We note that the number of arrests does not imply the total number of illegal fishing vessels. Given that 10 vessels were reported as committing 252 acts of illegal fishing, these numbers are likely very conservative.

\section{Mauritania and the Gambia}

The baseline illegal catch for Mauritania and The Gambia was extracted from Belhabib et al. (2012b) and Belhabib et al. (2016), respectively. These were then multiplied by the regional trend

\footnotetext{
${ }^{2}$ http://slconcordtimes.com/60-illegal-fishing-in-salone-waters/

${ }^{3}$ http://blogs.ubc.ca/jdmayer/2014/11/20/from-cannons-to-canon-sinkingpirate-fishing-in-sierra-leone/

${ }^{4} \mathrm{http} / / /$ cocorioko.info/now-it-is-time-for-sierra-leone-to-turn-attention
}

estimated using the total catch for Senegal, Guinea, Guinea Bissau, and Sierra Leone.

\section{Estimation of Unreported Foreign Catches}

To estimate unreported catches by the foreign fleets legally operating in West Africa, we first estimated the total catch based on the product of the fishing effort (defined as the number of vessels, their GRT, the number of fishing days and their nationality and gear type), and the catch corresponding to that unit of effort (Belhabib et al., 2014a). The number of foreign vessels operating in Senegal, The Gambia, Sierra Leone, Guinea Bissau, and Mauritania were obtained from national governmental organizations during a workshop in 2016, verified and/or complemented with the number of foreign vessels legally operating in the region obtained from official records (e.g., FAO global fishing vessel database ${ }^{5}$ ) whenever available completed by a literature review (Anon, 2015). The foreign catch from Guinea was extracted as a sub-set of the total catch, to which an underreporting rate of $20 \%$ was applied (Belhabib et al., 2012c). The difference between the reported foreign catch (extracted from official statistics provided by MCS units whenever available) and the total estimated catch represents the unreported foreign catch, which is obtained by flag for Senegal, Guinea Bissau, Sierra Leone, and Mauritania.

\section{Economic Loss}

The annual economic loss caused by illegal and unreported fishing was estimated by multiplying the estimated illegal and unreported catch by the ex-vessel price. Ex-vessel prices were obtained from the Sea Around Us ex-vessel price database for 2010 (Swartz et al., 2013) and converted to 2015 USD using Consumer Price Index extracted from the World Bank database (www.worldbank.org).

Although conservative, the values of unregulated catches were also added. The unregulated catch was estimated using the number of vessels that were caught while committing an unregulated fishing act such as illegal transshipment, fishing in a prohibited zone, using illegal mesh size, etc. multiplied by the

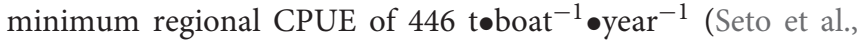
2015). This provides a rather highly conservative estimate since only those who were caught are taken into consideration in the analysis.

\section{Assessing the Effectiveness of MCS Using a Scoring System}

Sumaila et al. (2006) describe expected penalty drivers (or cheating drivers) as closely related to the effectiveness and efficiency of the surveillance system, the level of nongovernmental or private organizations involvement in detecting offenses, which relate to the likelihood of vessels of being detected; avoidance activities of offenders; and the severity of the penalty which disincentivises illegal fishing when it is accompanied by effective enforcement. Herein, we look at these drivers which are the likelihood of vessels of being detected through the number of offenses and sanctions, the avoidance activities which are represented by the number of offenses

${ }^{5}$ http://www.fao.org/figis/vrmf/finder/search/\#.V9BNKfkrKM9 
that escape sanctions and the severity of the penalty. We add availability of information as a proxy for transparency and develop a scoring system based on the indicators below:

1) Average fine amount: The weighted average fine amount was calculated for every country and normalized by the maximum amount (The Gambia) to a scale of 5 , where 5 is the best score and 1 the worst. This indicator illustrates the severity of the sanction.

2) Number of fined offenders in contrast to the number of total offenders: This indicates the number of vessels that get effectively fined over the total. This indicator is normalized to a scale of 5 , where 5 is the best score and 1 is the worst. This indicator illustrates avoidance.

3) Categories of offenses effectively fined: This indicator illustrates the frequency of vessels of being detected and fined, and ranges between 0 and 23.

4) Catch value per shelf unit: This indicator represents the concentration of the illegal catch, i.e., the amount of fish caught illegally per square $\mathrm{km}$ of continental shelf area. This indicator is a proxy for the severity of illegal fishing per country. This was calculated by first dividing the average value of the illegal catch (2010-2014) by the shelf area for each country, transformed to a log scale then reversed. We then normalized the value to a scale of 5 .

5) Availability of information: This parameter captures transparency while dealing with illegal fishing, as high transparency reduced bribing and corruption. This indicator is calculated as the sum of 6 sub-parameters scored with 1 for good and 0 for bad: (1) Names of offenders (vessels) available from government records, (2) fines available from government or any other sources, (3) offense category or type available from government or any other sources, (4) information is not aggregated in such a way that masks paid fines and offenses, (5) information is easy to obtain upon request and finally, (6) information is publically available. The scale of this indicator is between 0 and 6 .

The total score is then calculated as the sum of the previous scores, where the maximum score is 44 (based on the sum of the maximum of each score).

\section{RESULTS}

\section{Illegal Fishing Activities and Sanctions}

Overall, there were $230^{6}$ observed offenses which spread over 23 offense categories, or observed offenses that have been detected and mostly sanctioned in the region (Table 1). Around one third of the offenses observed were not sanctioned. Under-reporting of fishing effort (associated with GRT) represents the most recurrent offense. However, this offense is only sanctioned 19\% of the time, while it remains undetected by the governments of West Africa the rest of the time. Only Senegal applied sanctions on 12 vessels of Chinese origin of around \$1,000 US each. Gear related offenses (associated with illegal mesh size, illegal gear, improper stowage of fishing gear, etc.) were caught 44 times

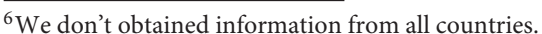

TABLE 1 | Summary of observed offenses in West Africa, 2009-2016.

\begin{tabular}{|c|c|}
\hline Offense & Number \\
\hline Under-reporting of fishing effort & 63 \\
\hline Gear related offense & 44 \\
\hline Fishing in a prohibited zone & 43 \\
\hline Fishing without a license & 19 \\
\hline Forgery-marking default & 17 \\
\hline Unauthorized entry or exit to or from EEZ & 16 \\
\hline Fishing without an authorization & 14 \\
\hline Mistreatment- corruption-failure to comply & 14 \\
\hline Absence of an observer onboard & 9 \\
\hline Under-reporting of fishing catch & 9 \\
\hline Administrative delays caused arrest & 8 \\
\hline Illegal trans-shipment & 8 \\
\hline Absence of national crew onboard & 7 \\
\hline Technical negligence & 6 \\
\hline Absence of proper documentation onboard & 5 \\
\hline Change of target species & 3 \\
\hline VMS-AIS default & 3 \\
\hline Prohibited species or juveniles & 2 \\
\hline Failure to land catch & 2 \\
\hline Illegal discard & 1 \\
\hline Failure to pay fees & 1 \\
\hline Sanitary and health issues & 1 \\
\hline Violating fishing regulations/unspecified & 41 \\
\hline
\end{tabular}

overall and were sanctioned entirely, with an average fine of $\$ 137,000$ US ranging between $\$ 835$ US (Senegal) and $\$ 812,000$ US (The Gambia). Fishing in a prohibited zone ranks third with 43 instances and sanctioned $50 \%$ of the time only, with an average fine of $\$ 134,000$ US, driven by high sanctions in Sierra Leone. Registered vessels fishing without a license were caught 19 times and were fined $\$ 179,260$ US on average, with an average fine of $\$ 45,000$ US in Senegal (the minimum) and a maximum in The Gambia ( $\$ 1.1$ million US). Forgery of documents, vessel names and marking fault were severely sanctioned in Sierra Leone with an average fine of $\$ 302,000$ US per offense in comparison with Guinea’s average ( $\$ 30,000$ US) and Senegal (\$800 US). Unauthorized entry to or exit from the EEZ of Sierra Leone constituted the sixth offense that was most caught in the region, and was sanctioned with a fine of $\$ 55,100$ US on average. Fishing without an authorization ranks seventh and was caught 14 times. Sanctions for this offense vary greatly from withdrawal of fishing license and a fine of $\$ 800$ US (Senegal) to around \$2.3 million US (Senegal). The next most recurrent categories of offenses consist of mistreatment (of fishing observers), attempted corruption and/or failure to comply with 14 vessels and an average fine of $\$ 95,600$ US per sanction driven by high sanctions in Sierra Leone.

\section{Value Recovered through MCS (Total Sanctions)}

Over the period between 2009 and mid-2016, around \$29 million US were collected or sanctioned in fines. 
Total fines collected or to be collected have increased overall from less than $\$ 370,000$ US in 2009 to a projected $\$ 13.8$ million US in 2016 (Figure 1). In contrast, the average fine per sanction has decreased, from the first peak in 2010 (\$362,000 US) to $\$ 137,000$ US in 2016 (Figure 1). This corresponds to the increase in the number of offenses (Figure 2). However, the number of offenses not related to fishing without authorization, such as entry or exit to or from EEZ without authorization, or gear type related offenses have increased which contributed to decrease the average sanction amount per sanction (Figure 1).

Overall, the number of caught offenses increased prompting an increase in the total amount recovered, from as low as 2 observed offenses in 2009 to 78 in 2014, declined to 43 observed offenses in 2015, caused by the low MCS in Sierra Leone and Guinea during the Ebola crisis (Figure 2), and then increased to a projected 98 caught offenders in $2016^{7}$ (Figure 2).

Comparing the profile of fines per offense in each country allows a better understanding of the effectiveness of the legislative background allowing MCS to recover its operating costs. Hence, both the number of sanctions (or caught offenders) and the average sanction amount are important. The highest number of offenses occurred in Guinea Bissau and Guinea, however the sanction is either low or not enforced (when observed by an NGO for example) with on average $\$ 24,900$ US per offense in Guinea and $\$ 81,800$ US in Guinea Bissau and a cumulated number of offenses of 109 and 72, respectively. In comparison, The Gambia has the lowest number of caught offenders (11), however charges the highest amount per offense (\$395,000 US), and more efforts need to focus on MCS to effectively sanction the offenders. Senegal and Sierra Leone have both a high number of offenders with 50 and 78 caught offenders, respectively, and a high average sanction per offense ( $\$ 181,000$ and $\$ 168,000$ US, respectively).

${ }^{7}$ For Buinea Bissau, 14 and 17 vessels were sanctioned in 2015 and 2016 (January to August), respectively. However, given the lack of information on the nature of the offense, it was not possible to fill in the gap in the fines using the Bissau Guinean legislation. Multiple cases in 2004 illustrate that fines revolve around an average of \$151,611 US (Tribunal International De La Lois Pour La Mer., 2010).
In addition to high fines and a relatively high number of caught offenders, Sierra Leone MCS detects and fines most categories of offenses (in constraints to detecting the offenders themselves), with the exception of prohibited species, which tends to be merged in the last category, i.e., unspecified violation of fisheries regulations, followed by Senegal (Figure 3).

\section{Total Reconstructed Illegal Catches}

Illegal catches, i.e., catches taken illegally by foreign fleets, were overall constant at around an average of 690,000 t•year ${ }^{-1}$ between 2010 and 2015. Country estimates vary widely (Figure 4). Illegal catches were the highest in Mauritania and Senegal with 268,000 and 261,000 toyear $^{-1}$ respectively, due to the presence of Eastern European pelagic trawlers targeting small-pelagic fish in high quantities (Figure 4). However, improving success of MCS due to the availability of funding (The World Bank, 2016), has prompted illegal catches to decline from around 350,000 to 250,000 t•year ${ }^{-1}$ between 2010 and 2015 for both countries. Illegal catches in Sierra Leone declined at first from 10,000 tøyear $^{-1}$ in 2010 to less than 3,500 tøyear $^{-1}$ in 2014,

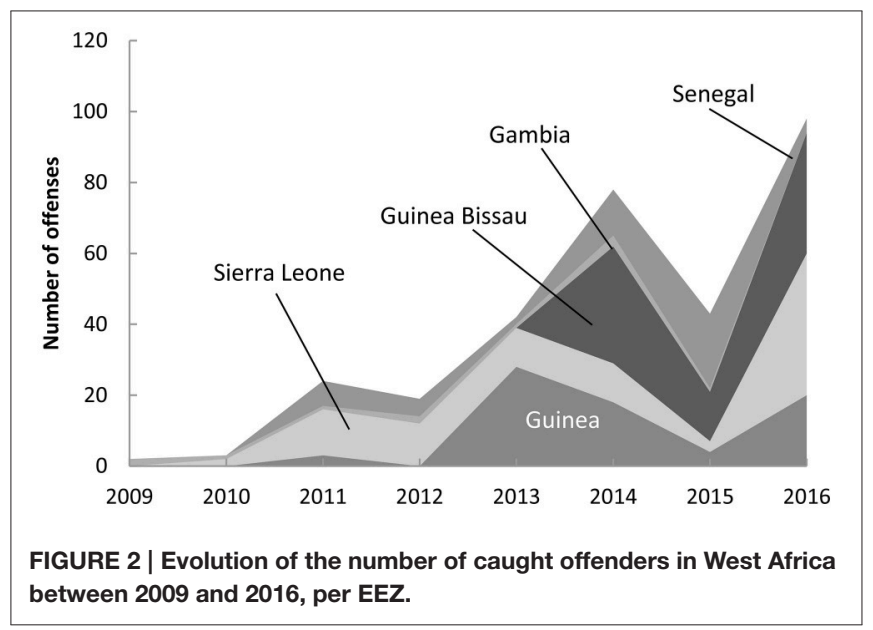

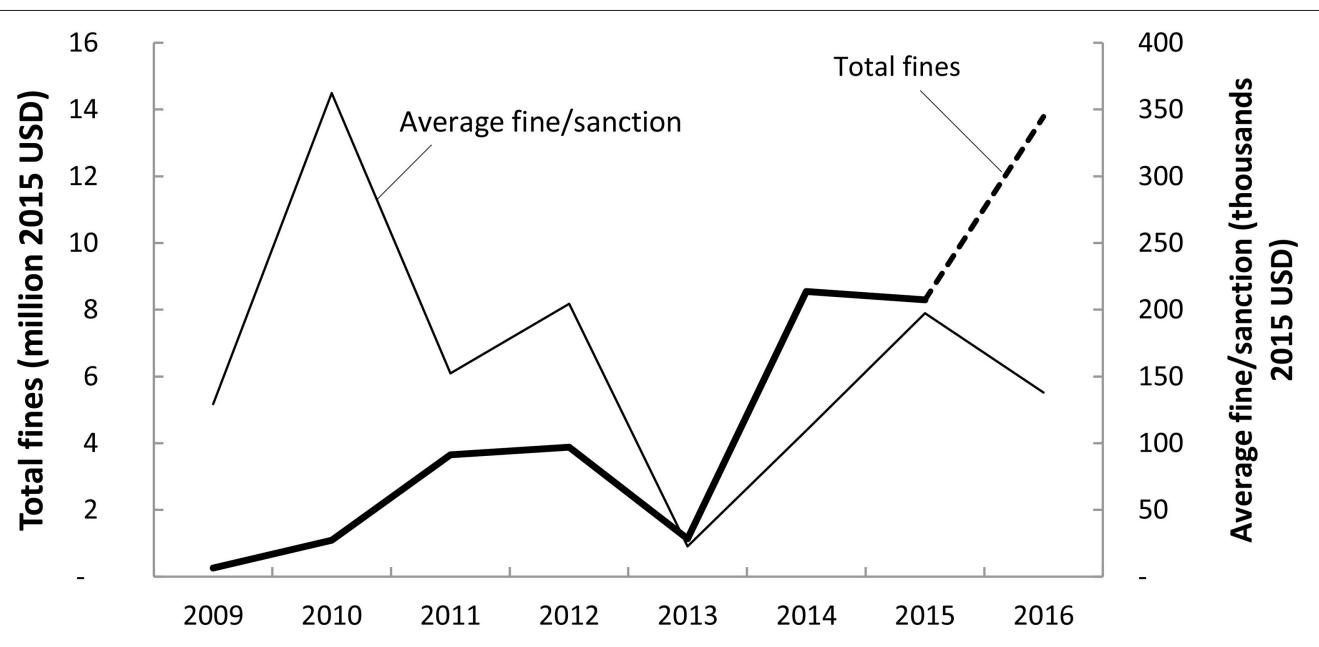

FIGURE 1 | Total (thick line) and average (thin line) fine amounts in West Africa, 2009-2016. 


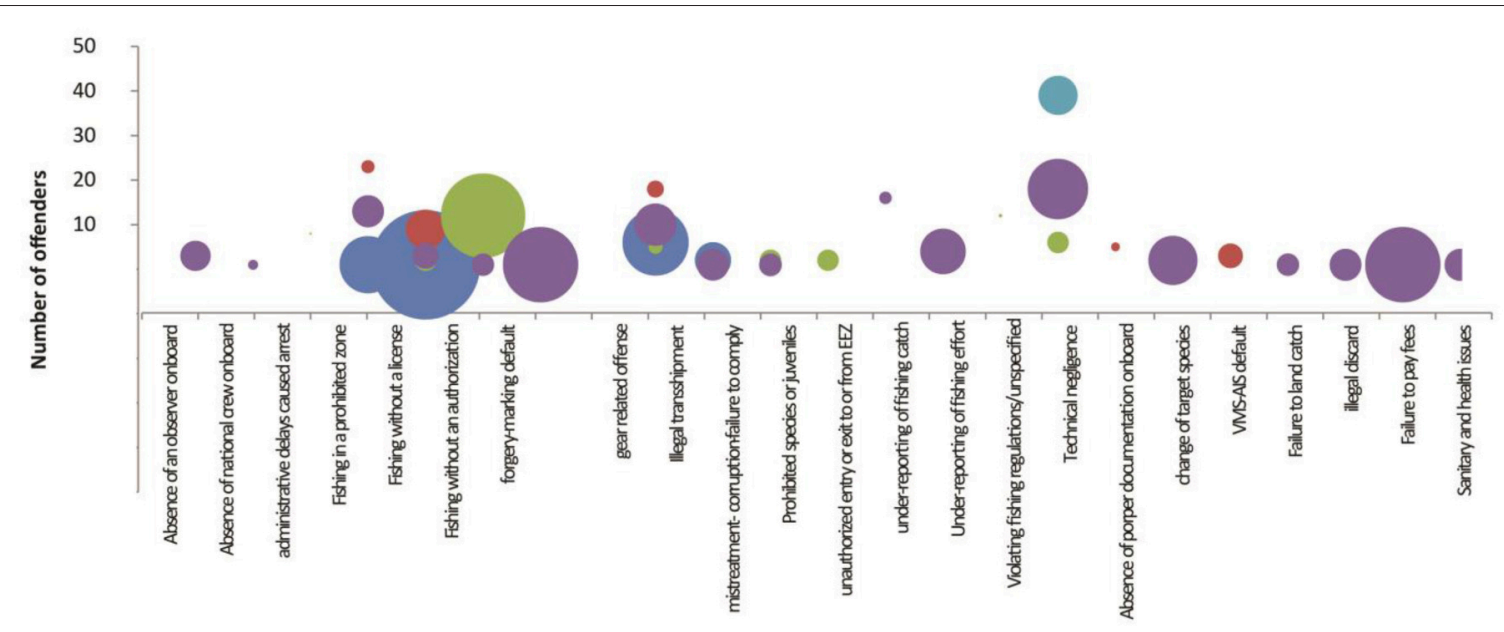

FIGURE 3 | Profile of fine and number of caught offenders by type of offense in Sierra Leone (purple), Senegal (green), Guinea (red), Guinea Bissau (light blue), and The Gambia (dark blue), 2010-2016. The size of circles represents to the amount of the (average) fine for the offense by country.

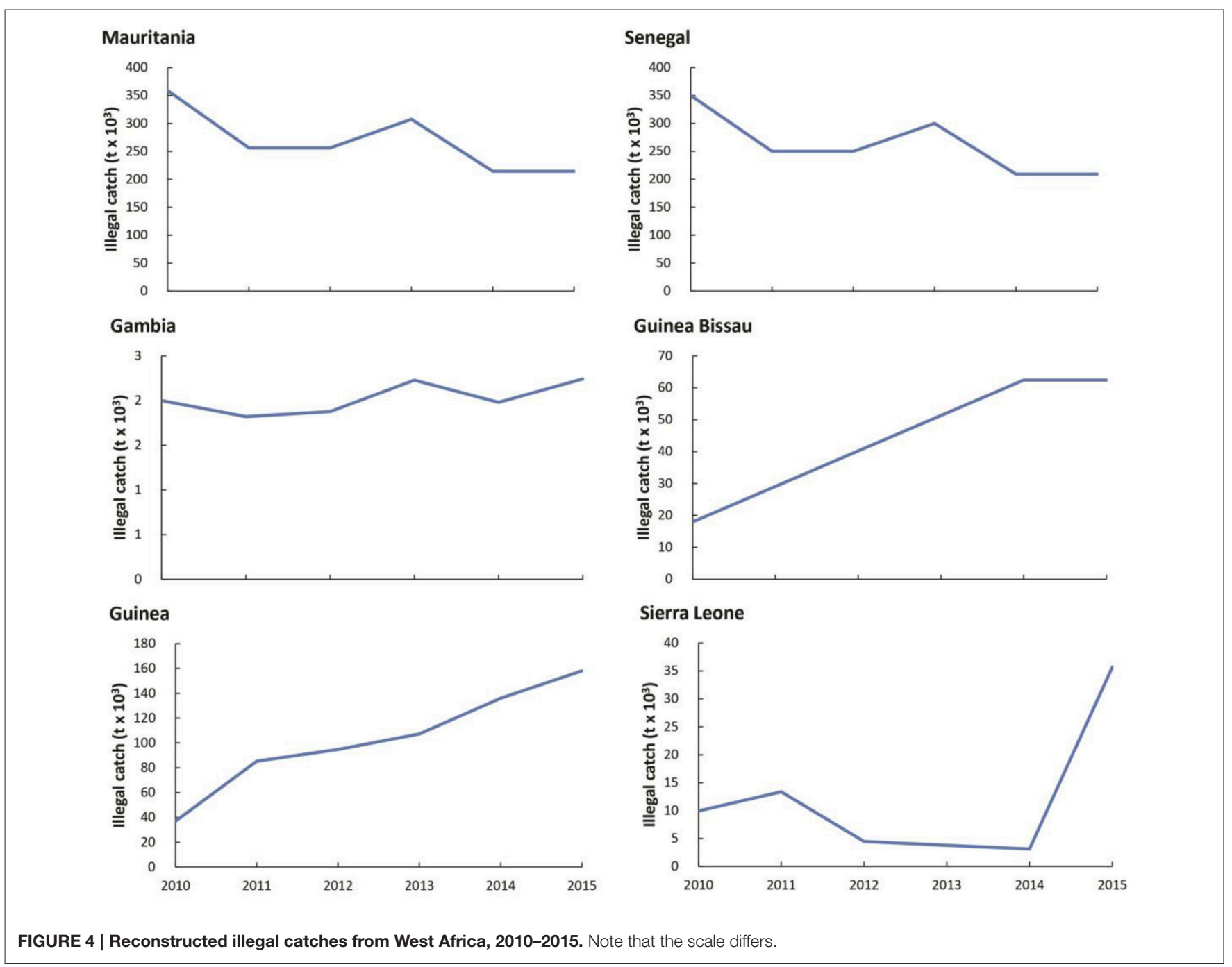


after which they increased drastically due to the Ebola crisis, to reach 35,000 toyear $^{-1}$ in 2015 (Figure 4). Illegal catches in Guinea increased from 40,000 tøyear $^{-1}$ in 2010 to over 150,000 t•year ${ }^{-1}$ in 2015 (Figure 4). Similarly, illegal catches in Guinea Bissau increased from less than 20,000 tøyear $^{-1}$ in 2010 to over 60,000 teyear $^{-1}$ in 2015 (Figure 4). Illegal catches in The Gambia remained overall constant with slight variation, at 2,000 t•year ${ }^{-1}$ on average between 2010 and 2015 (Figure 4).

\section{Economic Value of IUU Catches}

IUU in the waters of west Africa induced, at least, a loss of \$2.3 billion US annually, most of which is caused by illegal fishing, or fishing without an authorization and under-reporting by fleets that are otherwise authorized to fish in West Africa (Table 2). IUU losses increased from $\$ 1.8$ billion in 2010 (with $\$ 1.1$ million recovered through fines) to $\$ 2.2$ billion in 2012 ( $\$ 0.2$ million recovered through fines), decreased to $\$ 2$ billion between 2013 (\$0.02 million USD recovered through fines) and 2014 (\$8.5 million recovered through fines), after which they increased to a maximum of $\$ 2.3$ billion in 2015 (Table 2) during and after the Ebola crisis in Sierra Leone and Guinea, and after the departure of the World Bank and Environmental Justice Foundation from Sierra Leone, whose programs were key in increased monitoring in the country.

Overall, under-reporting alone contributed to a loss of value of $\$ 2$ billion over the period from 2010 to 2015, of which $30 \%$ is contributed by East European countries and Russia, $20 \%$ by Western European countries, which is at the same level than China, and $9 \%$ by flag of convenience countries, and $21 \%$ by unknown/unidentified countries. This illustrates that the lack of monitoring also reflects upon fleets that are legally entitled to fish in the waters of the West African sub-region. Over a period of 6 years, between 2010 and 2015, West African countries lost a total of \$ 24.6 billion US to IUU fishing, around half of which is taken by vessels that are not authorized to operate in their waters.

\section{Assessing the Effectiveness of MCS}

Using a set of indicators allows to assessing the effectiveness of MCS in West Africa within the regional standard of capabilities. A similar analysis at the global level would warrant a more effective assessment of MCS in the sub-region. This assessment hence takes into account realities of the region, such as governance, human and financial means, corruption, etc. This aims at learning from regional trends lessons that are realistically implementable within a limited means framework.

TABLE 2 | Loss induced by illegal, unregulated, and unreported fishing in West Africa, 2010-2015 in million $\$$ US $_{2015}$.

\begin{tabular}{ccccc}
\hline Year & Illegal value & Unreported value & Unregulated value & Total IUU \\
\hline 2010 & 1,459 & 376 & 0.1 & 1,836 \\
2011 & 1,669 & 376 & 6.2 & 2,052 \\
2012 & 1,608 & 543 & 4.6 & 2,155 \\
2013 & 1,831 & 177 & 3.8 & 2,011 \\
2014 & 1,704 & 285 & 11.4 & 2,000 \\
2015 & 1,996 & 263 & 4.1 & 2,263 \\
Total & 10,267 & 2,020 & 30.2 & 12,317
\end{tabular}

Of a maximum score of 44, Sierra Leone scores 33.5, followed by The Gambia with 24, Guinea with 23.3, Senegal with 22.7, and Guinea Bissau with 13.4, respectively (Table 3). It appears from this ranking that Sierra Leone's MCS ranks first in the region, despite an increased illegal catch during the Ebola crisis. Senegal does not appear to be scoring the highest despite clear efforts at the end of 2015 with the adoption of new historical fine legislations, and a new Fisheries Act. The time series used here may affect the scoring with most vessels being caught during a relatively recent time period.

\section{DISCUSSIONS}

This study estimates that illegal fishing in West Africa is responsible for a loss of over $\$ 2.3$ billion US a year, of which only $\$ 13.8$ million US/year (2016 baseline) are recovered through MCS. It also sheds light on the types of offenses that are prevalent in the region and the sanctions therein, and through a cross country comparison, illustrates gaps in monitoring. This gap is further illustrated herein by the total economic loss generated by IUU activities amounted 1.8 billion USD in $2010(<0.1 \%)$, when only 1.1 million USD were recovered through fines. The IUU losses then increased to 2.3 billion USD in 2015, when 8.2 million USD was recovered through fines $(0.4 \%)$.

This study documents 230 observed offenses and ranks them based on the most prevalent ones in the West African subregion. Over the 23 offense categories, 22 are committed by vessels authorized to fish in the waters of Senegal, The Gambia, Guinea Bissau, Guinea, and Sierra Leone. Under-reporting of the fishing effort is the most prevalent offense, which remains mostly unsanctioned. This offense relates to the fact that fishing fees are paid, mainly, based on the total Gross Registered Tonnage (GRT), and vessels from Asia were found under-reporting their GRT (Greenpeace, 2016b) to reduce their fishing fees. This offense alone could add another 520,000 \$ of non-paid GRT fees (Greenpeace, 2016b) to the loss incurred due to IUU fishing. This study also finds that offenses that have a severe impact on small-scale communities were also prevalent with gear related offenses (catching juvenile and prohibited species and fishing in prohibited zones such as artisanal areas). These offense types rank second and third and were more likely to be detected and sanctioned than other offenses. The presence of non-governmental organizations working with small-scale communities enhances the detection of such infractions (Sumaila et al., 2006).

Illegal catches are based on a reconstruction method whose uncertainty is discussed in previous analyses (Belhabib et al., 2016). Over the $\$ 2.3$ billion US lost to IUU, only $\$ 13.8$ million were recovered through MCS, in 2016. However, encouraging signs illustrate that while the number of detected offenses is increasing, the average sanction per offense is decreasing, alongside with a change in the profile of offenses to less severe offenses (according to national regulations). The rise of the Ebola crisis has slowed down the ability of MCS units in Guinea and Sierra Leone, and hence the total recovered fine, however, this total continues to increase. By developing the first regional database for offenses and sanctions, this study introduces the first scoring system that ranks MCS in West Africa, by looking at the 
TABLE 3 | Scoring of the MCS system in West Africa ${ }^{8}$.

\begin{tabular}{|c|c|c|c|c|c|c|}
\hline Country & $\begin{array}{l}\text { Amount (normalized by the } \\
\text { maximum average fine) }\end{array}$ & $\begin{array}{c}\text { Number of Fined offenders } \\
\text { weighted by maximum in } \\
\text { Guinea ( } \max =5 \text { ) }\end{array}$ & $\begin{array}{l}\text { Categories } \\
\text { fined }\end{array}$ & $\begin{array}{l}\text { log of catch value } \\
\text { per shelf } \mathrm{km}^{2}\end{array}$ & $\begin{array}{l}\text { Availability of } \\
\text { information }\end{array}$ & Total score \\
\hline Senegal & 2.29 & 5.00 & 9 & 4.45 & 2 & 22.7 \\
\hline Gambia & 5.00 & 5.00 & 5 & 5.00 & 4 & 24.0 \\
\hline Guinea Bissau & 1.03 & 3.25 & 3 & 4.15 & 2 & 13.4 \\
\hline Guinea & 0.30 & 3.47 & 12 & 3.56 & 4 & 23.3 \\
\hline Sierra Leone & 2.08 & 5.00 & 17 & 3.43 & 6 & 33.5 \\
\hline
\end{tabular}

fine amounts, the number of detected offenders, the categories of offenses that are effectively fined, the illegal catch value and the transparency of the information system, which could be reproduced in other regions of the world, and could be adjusted for data availability. Scoring analysis indicates that despite the Ebola crisis, Sierra Leone was the most effective in detecting and sanctioning (with considerably higher fines) illegal fishing both in number and amounts. This is, however, to be taken with caution, as data on the number of offenses relative to the number of operating vessels were not available at the time of this study. Further, such database could serve as a benchmark for fining and sanctioning, particularly with repeat offenders. Examples show that when information with regards to previous offenses by a vessel is available, the fine is inflated, which is in the advantage of the fining country ${ }^{9,10}$.

Illegal catches decreased in Senegal, Mauritania, and Guinea Bissau and increased by 3 -fold in Guinea and by 4 -fold in Sierra Leone, due mainly to the Ebola crisis, and despite drastic measures such as red cards emitted by the EU. In addition, the suspension of the West Africa Regional Fisheries Programme funded by the World Bank which assured major funding for MCS activities, and Environmental Justice Foundation, which played a major role in both training and enhancing MCS capabilities in Sierra Leone, prompted a major increase in illegal catches in the country. These increases drive the trend of illegal fishing upwards, and hence the value from $\$ 1.8$ billion in 2010 to $\$ 2.3$ billion in 2015, which cumulates to $\$ 12.3$ billion during the same time period. Vessels legally operating in the region are under-reporting the equivalent of $13 \%$ of this value.

Overall, the results of this study show that countries of West Africa are vulnerable to IUU fishing, which is not news. The contrast in MCS capacity between Mauritania (Beibou, 2015) and Senegal in the north and Guinea to Sierra Leone in south is evident through the trends in illegal catches. However, Sierra Leone scoring highest for MCS is an indicator that-in the absence of major constraints such as Ebola-, encouraging signs of increased efforts to combat illegal fishing are shown. Even though all these countries are part of the Sub-Regional Fisheries Commission which has joint surveillance capabilities, investment in MCS has been much higher in the

\footnotetext{
${ }^{8}$ Due to the absence of information the Mauritanian MSC was nor considered in this analysis. We note however that this study was done after Mauritania joined the Fisheries Transparency Initiative and hope that similar analysis could be performed for Mauritania in the near future.

${ }^{9} \mathrm{http}: / /$ www.bbc.com/news/world-africa-25621864

${ }^{10} \mathrm{http} / / /$ researcherdiaries.com/2016/07/busted-the-gotland-to-pay-1-5-millioneuros-in-fines-to-the-government-of-senegal/
}

northern countries whose wide continental shelves and rich waters are more targeted by illegal fishing fleets, than in the south. This study further reveals that most detected offenses escaping sanctions occurs in countries such as Guinea and Guinea Bissau, where the rate of sanction is very low. Hence, it calls for the implementation of regional measures such as the right of pursuit which allows an offended country to pursuit the illegal fishing boat and to catch it in the EEZ of its neighboring country. Other efforts post-detection of offense should also be used, such as AIS tracing of vessel activities, as a proof of infringement in court, increased fines to disincentivize illegal fishing, and increased regional cooperation.

This study also finds that IUU fishing poses a serious threat to populations dependent on fish stocks and to the very safety of artisanal fishers. Among the most common infractions are incursions by trawlers into the zones reserved for artisanal fishers and these tend to occur at night, regularly causing fishers to lose their fishing gear and canoes, and has even resulted in the loss of lives (Doumbouya et al., 2004). In addition, recent analysis indicate that tackling illegal fishing in the region may result in regaining back 300,000 jobs (Daniels et al., 2016).

This analysis shows an important gap between the value of the loss generated by IUU fishing and the amount IUU vessels are effectively fined. It also shows that higher fines contribute into reducing incentives of illegal fishing through a higher capability of catching offenders (increased resources for MCS), and providing higher incentives to avoid being caught. This study recommends, beyond addressing the lack of human and financial resources for MCS efforts:

- Increased sanctions against e.g., repeat offenders and foreign illegal fishing: This can be done through strengthening the legal system.

Indeed, this study further illustrates that this legal framework exists in some countries of the sub-region, and whenever possible is applied appropriately. Both Guinea and Senegal's new Fisheries Acts inflict historically high sanctions for illegal fishing (Daniels et al., 2016).

- Issues of transparency, low governance and high corruption, and hence effective prosecution need to be addressed in the region: This region of the world is particularly targeted by major external funding for its MCS operations (The World Bank, 2016), capacity is focused on building the MCS network, 
while prosecution for higher fines, or the legislative system that allows for appropriate sanctions may be weak.

Perpetuating lower sanctions and fines makes MCS vulnerable to the availability of funding through external party contributions.

- It is hence very important to use low cost tools such as Automatic Identification System and Vessel Monitoring Systems for effective monitoring, to implement pre-existing legislations, such as the regional right of pursuit that allows countries to either follow or follow up on illegal fishing vessels regionally as illegal fishing takes a form of transnational activity and does not respect national boundaries.

\section{AUTHOR CONTRIBUTIONS}

$\mathrm{AD}, \mathrm{OC}$, and $\mathrm{DB}$ gathered, analyzed and interpreted data, discussed the results and co-wrote the manuscript. EB and

\section{REFERENCES}

Anon, (2015). Strategy and National Action Plan for the Biodiversity. Bissau: The Republic of Guinea Bissau; The State's General Office of the Environment.

Agnew, D. J., Pearce, J., Pramod, G., Peatman, T., Watson, R., Beddington, J. R., et al. (2009). Estimating the worldwide extent of illegal fishing. PLoS ONE 4:e4570. doi: 10.1371/journal.pone.0004570

Andrews-Chouicha, E., and Gray, K. (2005). Why Fish Piracy Persists: the Economics of Illegal, Unreported, and Unregulated Fishing. Paris: Organization for Economic.

Beibou, E. (2015). Géomatique collaborative: mise en œuvre d'un système d'information pour la pêche responsable en Mauritanie. Nouadhibou: Imrop.

Belhabib, D., Copeland, D., Gorez, B., Harper, S., and Zeller, D. (2012a). "Guinean fisheries: past, present and future," in Marine Fisheries Catches in West Africa, eds D. Belhabib, S. Harper, D. Zeller, and D. Pauly (Vancouver, BC), 91-104.

Belhabib, D., Gascuel, D., Abou Kane, E., Harper, S., Zeller, D., and Pauly, D. (2012b). "Preliminary estimation of realistic fisheries removals from Mauritania: 1950-2010," in Marine Fisheries Catches in West Africa, Part 1, eds D. Belhabib, D. Zeller, S. Harper, and D. Pauly (Vancouver, BC), 61-78.

Belhabib, D., Harper, S., Zeller, D., and Pauly, D. (eds.). (2012c). Marine Fisheries Catches in West Africa, 1950-2010, Part I. Vancouver, BC.

Belhabib, D., Koutob, V., Lazar, N., Ndiaye, V., Tobey, J., Mathews, C., et al. (2014a). Beyond the Unseen: A First Collaborative Model Towards Estimating Illegal, Unreported, and Unregulated Catches off Senegal. Fisheries Centre Working Papers, Vancouver: University of British Columbia.

Belhabib, D., Koutob, V., Sall, A., Lam, V. W., and Pauly, D. (2014b). Fisheries catch misreporting and its implications: the case of Senegal. Fish. Res. 151, 1-11. doi: 10.1016/j.fishres.2013.12.006

Belhabib, D., Koutob, V., Sall, A., Lam, V. W., Zeller, D., and Pauly, D. (2015a). Counting pirogues and missing the boat: reply to Chaboud et al.'s comment on Belhabib et al."Fisheries catch misreporting and its implications: the case of Senegal”. Fish. Res. 164, 325-328. doi: 10.1016/j.fishres.2014.09.016

Belhabib, D., Mendy, A., Subah, Y., Broh, N. T., Jueseah, A. S., Nipey, N., et al. (2016). Fisheries catch under-reporting in The Gambia, Liberia and Namibia and the three large marine ecosystems which they represent. Environ. Dev. 17, 157-174. doi: 10.1016/j.envdev.2015.08.004

Belhabib, D., and Pauly, D. (eds.). (2015). Marine Fisheries Catches in West Africa, 1950-2010, Part II. Vancouver, BC.

Belhabib, D., Sumaila, U. R., Lam, V. W., Zeller, D., Le Billon, P., Kane, E. A., et al. (2015b). Euros vs. Yuan: comparing European and Chinese fishing access in West Africa. PLoS ONE 10:e0118351. doi: 10.1371/journal.pone.0118351
AP edited the manuscript and discussed the results, JM, JI, SC, AJ, AG, and DN gathered data and discussed the results.

\section{ACKNOWLEDGMENTS}

This study is a contribution of West African fisheries specialists who participated in a West Africa capacity Building Workshop at the University of British Columbia Institute for the Oceans (IOF) and Fisheries, and the Sea Around Us toward the project "Marine Conservation Research, Collaboration and Support in West Africa", funded by the MAVA Foundation. The Sea Around Us is a scientific collaboration at the University of British Columbia funded by the Paul G. Allen Family Foundation. The authors thank the IOF staff, faculty and students for their hospitality during the workshop, and colleagues in West Africa for the valued information.

Belhabib, D., Sumaila, U. R., and Pauly, D. (2015c). Feeding the poor: contribution of West African fisheries to employment and food security. Ocean Coast. Manage. 111, 72-81. doi: 10.1016/j.ocecoaman.2015.04.010

Caopa, and Rejprao, (2016). Voices from African Artisanal Fisheries. Calling for an African Year of Artisanal Fisheries. Dakar: CAOPA.

Daniels, A., Gutierrez, M., Fanjul, G., Guerena, A., Matheson, I., and Watkins, K. (2016). Western Africa's Missing Fish. The Impacts of Iunreported and Unregulated Fishing and Under-Reporting Catches by Foreign Fleets. London: Overseas Development Institute.

Doumbouya, A., Guilavogui, A., and Lefur, J. (2004). Accès à l'Espace et à la Ressource: Compétition et Conflits entre la Pêche Artisanale et la Pêche Industrielle Dans la ZEE Guinéenne. Conakry: Document Scientifique; CNSHB.

Environmental Justice Foundation (2012). Pirate Fishing Exposed. The Fight Against Illegal Fishing in West Africa and the EU. London: Environmental Justice Foundation.

FAO (2016). The State of World Fisheries and Aquaculture. Contributing to Food Security and Nutrition for All. Rome: Food and Agriculture Organisaton.

Finch, R. (2016). The Evil Empire. How Common Fisheries Policy is Recolonising the Third World. Brussels: Europe of Freedon and Direct Democracy.

Greenpeace (2006). Witnessing the Plunder. How Illegal Fishing from West African Waters finds its way to the EU Ports and Markets. London: Greenpeace.

Greenpeace (2016a). Africa's Fisheries' Paradise ar a Crossroads. Investigating Chinese Companies' Illegal Fishing Practices in West Africa. Dakar: Greenpeace.

Greenpeace (2016b). Scam on the African Coast. Dakar: Greenpeace.

INTERPOL (2014). Study on Fisheries Crime in the West African Coastal Region. Lyon: INTERPOL.

Le Gallic, B., and Cox, A. (2006). An economic analysis of illegal, unreported and unregulated (IUU) fishing: key drivers and possible solutions. Mar. Policy 30, 689-695. doi: 10.1016/j.marpol.2005.09.008

MRAG (2005). Review of Impacts of Illegal, Unreported and Unregulated Fishing on Developing Countries. London: MRAG.

NOAA (2015). Improving International Fisheries Management. Report to Congress persuant to section 403(a) of the Magnuson-Stevens Fishery Conservation and Management Reauthorization Act of 2006. Washington, DC.

Pauly, D., Belhabib, D., Blomeyer, R., Cheung, W. W., Cisneros-Montemayor, A. M., Copeland, D., et al. (2014). China's distant-water fisheries in the 21st century. Fish Fish. 15, 474-488. doi: 10.1111/faf.12032

Seto, K., Belhabib, D., Copeland, D., Vakily, M., Seilert, H., Sankoh, S., et al. (2015). Colonialism, Conflict, and Fish: A Reconstruction of Marine Fisheries Catches 
for Sierra Leone, 1950-2010. Vancouver, BC: Fisheries Centre Working Paper, University of British Columbia.

Standing, A. (2006). Corruption and Commercial Fisheries in Africa. U4Brief. Cape Town: Chr. Michelsen Institute.

Sumaila, U. R., Alder, J., and Keith, H. (2006). Global scope and economics of illegal fishing. Mar. Policy 30, 696-703. doi: 10.1016/j.marpol.2005.11.001

Swartz, W., Sumaila, R., and Watson, R. (2013). Global ex-vessel fish price database revisited: a new approach for estimating 'missing'prices. Environ. Resour. Econ. 56, 467-480. doi: 10.1007/s10640-012-9611-1

The World Bank (2016). West Africa Regional Fisheries Program (P106063). Implementation Status and Results Report. The World Bank, Washington, DC.

Tribunal International De La Lois Pour La Mer. (2010). Pleadings, Minutes of Public Sittings and Documents. Volume $12=$ Mémoires, Procès-Verbaux Des Audiences Publiques et Documents. Leiden; Biggleswade: Martinus Nijhoff; Extenza Turpin [distributor]
Conflict of Interest Statement: The authors declare that the research was conducted in the absence of any commercial or financial relationships that could be construed as a potential conflict of interest.

Copyright $\odot 2017$ Doumbouya, Camara, Mamie, Intchama, Jarra, Ceesay, Guèye, Ndiaye, Beibou, Padilla and Belhabib. This is an open-access article distributed under the terms of the Creative Commons Attribution License (CC BY). The use, distribution or reproduction in other forums is permitted, provided the original author(s) or licensor are credited and that the original publication in this journal is cited, in accordance with accepted academic practice. No use, distribution or reproduction is permitted which does not comply with these terms. 